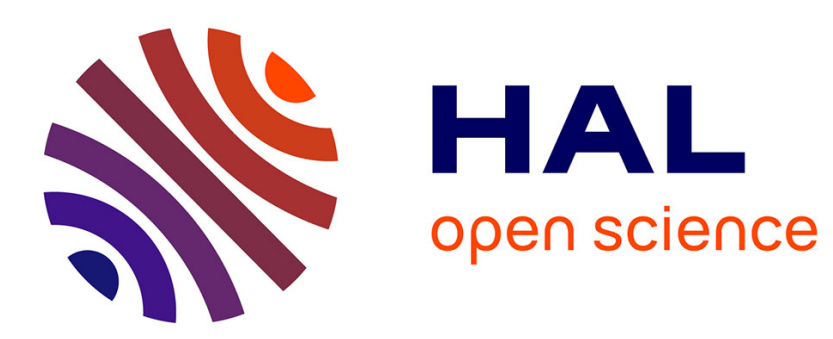

\title{
Reforming psychiatric institutions in the mid-twentieth century: a framework for analysis
}

Nicolas Henckes

\section{To cite this version:}

Nicolas Henckes. Reforming psychiatric institutions in the mid-twentieth century: a framework for analysis. History of Psychiatry, 2011, 22 (2), pp.164-181. 10.1177/0957154X11401867 . hal-02548878

\section{HAL Id: hal-02548878 \\ https://hal.science/hal-02548878}

Submitted on 21 Apr 2020

HAL is a multi-disciplinary open access archive for the deposit and dissemination of scientific research documents, whether they are published or not. The documents may come from teaching and research institutions in France or abroad, or from public or private research centers.
L'archive ouverte pluridisciplinaire HAL, est destinée au dépôt et à la diffusion de documents scientifiques de niveau recherche, publiés ou non, émanant des établissements d'enseignement et de recherche français ou étrangers, des laboratoires publics ou privés. 


\title{
Reforming psychiatric institutions in the mid-twentieth century: a framework for analysis
}

\author{
Nicolas Henckes
}

\begin{abstract}
:
This article develops an analytical framework of processes of institutional reform in psychiatry in Western countries during the last century. It discusses explanations of social change based on deinstitutionalization and proposes instead to put reform practices themselves at the center of the analysis. Central to this framework is thus the historicity of the idea of reform itself. Taking the case of France as an example, the article shows how the diffusion of a reformist ethos within psychiatry in the post-World War II period can be accounted for by a change in medical expertise during the first half of the century. It concludes with a discussion of the changing relationship between psychiatrists and the State in the twentieth century.
\end{abstract}

Keywords: deinstitutionalization; France; mental health policies; psychiatric work; reform movements.

Nicolas Henckes

Chargé de recherche CNRS

Centre de recherche médecine, science, santé, santé mentale et société (CERMES3)

7 rue Guy Môquet

94801 Villejuif Cedex

France

Tél. : +33149583571

Email : henckes@vif.cnrs.fr 


\section{Reforming psychiatric institutions in the mid-twentieth century: a framework for analysis}

It would be no exaggeration to define the thirty years following the Second World War as the age of reform in psychiatry, given the central place devoted during this period and within this field to questions of institutional reform. Never before nor since have so many people been interested in the problems of psychiatric hospitals. They had become an issue far beyond the narrow circle of political, administrative and professional elites who were customarily concerned by them. They were also at the heart of discussions on the very definition of psychiatry as a medical discipline. In a sense, for many professionals following the Second World War, reforming the psychiatric institution became a way of doing psychiatry. It is this age of reform that the present article intends to clarify. Based on the French case, it develops an analytical framework of processes of institutional reform in psychiatry in Western countries in the mid-twentieth century which proposes to put reform practices themselves at the center of the analysis. Reforming the psychiatric institution was a project with diverse meanings for many different actors, who made plans, developed experiments, sought support and disseminated ideas. Within this framework, attention is given to the meaning of these reform practices, to the way actors developed them, to the conditions making them possible as well as to their effects on institutions themselves.

To date, the historiography of reform in the psychiatric field has been largely dominated by an approach in terms of deinstitutionalization (but see Gijswijt-Hofstra et al., 2005, for a more complex picture; Goodwin, 1997; Jones, 1993; Prior, 1993; Rothman, 1980)¹. Its inquiry was motivated by the major transformations brought about within mental health systems

\footnotetext{
${ }^{1}$ Even Gerald Grob’s masterwork on mental health policies in America has used deinstitutionalization in its heading (Grob, 1991).
} 
beginning in the 1960s which, in a context of harsh criticism toward psychiatric institutions, resulted in the transfer of care towards structures more open to communities and the emergence of a new institutional landscape, both more fragmented and less specialized (Barham, 1992; Brown, 1985). Along with these changes, the period saw the emergence of new mental illness trajectories, marked by multiple rehospitalizations and recourse to a variety of social and medico-social facilities (Estroff, 1981). More broadly, deinstitutionalization was a reflection of the emergence of new ways of medicalizing society which sociologists have analyzed using the concepts of control or surveillance society, or more recently, of politics of life itself (Armstrong, 1995; Castel, 1991; Foucault, 1975; Rose, 2007).

However, while deinstitutionalization may be a good label for the transformations in mental health systems in the second half of the twentieth century, it is an unsatisfactory concept for understanding the historical processes of social change. Sociological and historical works on deinstitutionalization have tended to adopt a causal approach, trying to untangle the reasons behind the transformations of the psychiatric landscape. This led to a series of controversies that are as irresolvable as they are doubtless futile, bearing on the respective roles of psychotropic medications, neoliberal cost control policies or the antipsychiatry culture of the 1960s and 1970s (Bachrach, 1976; Scull, 1977). Analyses have tended to consider the numerous social movements, discussions and debates on asylums and psychiatric hospitals which have swept through psychiatry since the end of the nineteenth century as mere forerunners of the movements which would later actually lead to change (Castel, 1988; Dowbiggin, 1991). As a result, the uniqueness of the reform experience as it was shaped by actors at different moments in time tends to be lost. In this respect, two points merit further attention. 
The first concerns criticism of the psychiatric institution, its meaning and its impact. Several authors have shown it to be as old as the psychiatric institution itself (Fauvel, 2005; Goldstein, 1987). Indeed, the recurrent denunciations of the way patients were treated in institutions were in a way a reflection of the paradigmatic nature of their situation and their vulnerability when confronted with psychiatric authority. Historians' sympathy with these criticisms was often based on a mythical vision of care for the mentally ill by their community of origin ${ }^{2}$; furthermore, they precipitately concluded that criticizing psychiatric institutions was tantamount to the objective of getting patients out of them. Historical analysis should clarify the way criticisms were expressed, who their authors were, the problems they were targeting and their own practices while developing these criticisms ${ }^{3}$. Taking into account all these dimensions requires consideration of the heterogeneity of individuals' stances toward change in the psychiatric systems during the twentieth century. This heterogeneity is poorly accounted for simply by the general concept of deinstitutionalization.

The second point follows a similar line of reasoning. It concerns the temporal dimension of psychiatric hospital reform. Explanations of changes over time in attitudes about psychiatric institutions are generally based on analyses in terms of generations, of shifts in perspective and of crises. The emergence and spread of more liberal views on treating mental patients among young generations of psychiatrists is explained by the gradual decline of their elders and by their own maturation, by a crisis in one model and its replacement by a new one. However, sociologists of social movements have taught us to pay attention to the construction of collective action (Blumer, 1969; Gusfield, 1981; McCarthy and Zald, 1977). New generations do not simply emerge from an accumulation of actors. Reformers are not just

2 On this point see the comments by Prestwich (Prestwich, 1994).

3 See the perspectives elicited in the sociology of criticism by Luc Boltanski and Laurent Thevenot (Boltanski and Thévenot, 2006). 
people who reveal existing tensions. Promoting a cause implies carrying out certain actions to define a problem, to give it weight, to organize and unite interest groups around it.

Following on from these perspectives, the analytical framework I develop in this article focuses on reform practices themselves. It insists on the dynamics of construction of social problems as well as on the specificity of reform as an individual and collective experience. It relies on an analysis of the conditions, actions and interactions necessary for developing reform movements. For reformers, be they politicians, lawyers, physicians, bureaucrats or militants, commitment to reform meant making social change one's own goal. When they gained recognition from wider audiences, reformers eventually managed to give shape to social change. Reform processes are thus productive. They are also historically situated and, in a sense, it is the historicity of the issue of reform itself which is at the center of this analysis. The way reform was framed in psychiatry changed dramatically during the century. These changes concerned both the actors who committed themselves to reform and the way these actors addressed the problems of psychiatric institutions in a series of arenas.

The framework thus relies on two central questions. The first pertains to the conditions in which the transformation of psychiatric institutions became a project for individuals or groups. What made given actors in given situations prone to endorse this project and what made organizations, professional associations, commissions or parliamentary majorities, become interested and willing to put it on their agenda? In other words, what made reformist careers possible at each historical moment? At stake here is the issue of the meaning of commitment to reform for reformers themselves. The second question relates to the way actors behaved as reformers. Reform practices consisted of publishing pamphlets, redacting normative texts, devising in vivo experiments, building social movements, lobbying and defending one's positions in commissions. While developing these actions, actors expressed 
positions which reflected their world view and the conceptual tools they could rely on, but these were also contingent upon the audience they targeted and the specific goals that actors were pursuing while developing them. These actions were also framed by certain temporal dynamics. Reform movements have their own life; they go through phases of conquest, phases of organization and phases of routine. Their emergence is a reflection of the actors' awareness that routine is overtaking their institution, whereas their decline often gives rise to new projects.

By emphasizing these issues, this analysis hopes to better account for the popularity of the project of reforming psychiatric institutions in post-war Western societies. With their radical discourse and their far-reaching political and social implications, antipsychiatry movements in the 1960s and 1970s should be seen as the climax of a long series of reform movements in psychiatry since the end of nineteenth century. Rather than the changing conditions of the psychiatric institutions, I would like to argue that it was the way the idea of reform and of social change had evolved up to that time which made such movements possible. Central to this process was the emergence in this period of a new discourse on institutions developed by a new class of mental health worker, which was also central to the larger political and social movements at the time. This resulted in establishing, in the minds of these professionals, a new relationship between their own work and social change.

This framework also avoids the implicit normative stance of the deinstitutionalization approach and its temptation to provide an assessment of reform outcomes. Such a position is needed in the new context within which historians have had to deal with psychiatry for the past ten or twenty years. Back in the 1970s and '80s, historians and sociologists generally adopted a critical stance on psychiatric institutions and a progressive view of the rise of a more humanistic psychiatry. The renewal of biological psychiatry, the advent of the 
neurosciences, and the rise of managerial thinking within healthcare organizations have all recently brought into question this optimism (Burnham, 2000; Cooter, 2007). While fueling new forms of criticism, these changes should lead us to a reassessment of our moral positions when dealing with psychiatry. Some of these changes may come from the new interest of historians and sociologists in techniques (Braslow, 1997; Pressman, 1998), drugs and clinical research (Healy, 1997; Swazey, 1974; Tone, 2009), and more generally in the production of clinical knowledge and categories (Berrios, 1996; Hacking, 1995). The time has now come to use these approaches in the history of psychiatric institutions themselves.

The case of France will serve as an example ${ }^{4}$. Without doubt, French psychiatric reform movements had many distinctive characteristics. These were related to the centralized State government, to the relative weakness of the public health system and health policy in general, to the organization of French medical personnel around a very hierarchical university hospital system, and to the gradually growing distance between this system and psychiatric hospital physicians. From the 1920s on, the latter played a key role in defining and stimulating thinking about their institutions, an area largely overlooked by the university elites who dominated the rest of medicine. Because psychiatric hospitals were State institutions, the country’s higher-ranking administrative and political authorities were very much involved in their reform. In the early 1960s, this reform gave rise to the "secteur" policy, developed both as a tool for planning regional psychiatric services and as an organizational model for psychiatric work. The concept of secteur emphasized coordination between the different psychiatric facilities, under the direction of psychiatrists. The commitment of professionals to their institution and the central position of hospitals in the country's health policy led to keeping the psychiatric hospital at the center of the system. Doubts concerning this

4 This article is based on a larger project on reform in psychiatric hospitals in France during the 20th century (Henckes, 2007). 
arrangement were not raised until the second part of the 1970s with the insistence on the necessity of closing beds and developing psychiatry in general hospitals, which only took effect under the impetus of financial incentives. Concurrently, starting in the 1970s new social services developed as a consequence of disability policies that largely escaped psychiatrists' authority.

Yet, aside from these distinctive features, or perhaps because of them, the French situation exemplified many tendencies that also affected other Western countries. Among them were the importance in the post-war period of social psychiatry and the social sciences in general, the role of the State in organizing mental health systems, the trust conferred on professionals in defining and regulating health services, and the necessity of rethinking the coordination of the psychiatric system within society as a whole. More profoundly, because French reformers never questioned the existence of psychiatric institutions as such but tried to work out ways of creating and maintaining better institutions, the French case can help us understand the nature of these institutions as enduring elements within societies.

In the remainder of this article, I develop certain aspects of the reform of psychiatric institutions in France to illustrate this framework. In the first two sections, I suggest ways for positioning the specificity of the post-war period within the larger story of the reform of psychiatric institutions. Based on a mapping of both actors and projects following Adele Clarke's situational analysis approach (Clarke, 2005), I reflect on the overall evolution of attempts to reform psychiatric institutions, from approaches centered on the status of the mentally ill to approaches centered on the conditions of medical work within institutions after 1945. In the next two sections, I specifically look at the local context of attempts at reform. I analyze the logic behind reformist careers and the dynamics of their renewal until the 1970s. In conclusion, the last section of the article reflects on the evolution of the relationship of 
psychiatry to the State during the unfolding of the story.

\section{The social dynamics of reform}

In France, as in other countries, the history of institutional reforms in psychiatry is probably as long as the history of psychiatric institutions themselves. Ian Goldstein has described the opposition provoked by the passing of the law organizing the French mental health system in 1838 (Goldstein, 1987) and much has been written about the wave of systematic denunciation of asylums and alienists organized during the 1860s, which some historians did not hesitate to compare to the antipsychiatry crisis of the 1960s (Dowbiggin, 1991; Fauvel, 2005; Goldstein, 1987). Admittedly, in the latter case, psychiatry was the target of criticisms that could not be directly addressed to the regime. However, discussions about the mental health system also took the form of a long series of legal projects debated in Parliament during the Third Republic, from 1880 to 1939.

Thus, reforming psychiatric institutions was certainly not a new project after the Second World War, but it gained certain distinctive features. The most notable of these was probably the way in which professionals in the mental health field committed themselves to reform. Post-war psychiatric reform movements were exemplary in making a political issue of care and daily psychiatric work. This observation refers to at least two different aspects. The first was that psychiatric work itself became a topic for political discussion. One need only think of how, for certain groups of radical mental health professionals in the 1970s, caring for psychiatric patients became equated with defending a politically alienated individual. Psychiatric institutions became both a site of political struggle and a place of social 
experimentation $^{5}$. The second aspect was the role taken by professionals, at all levels of the State apparatus, in the definition and enactment of health and social policies. More than ever before, psychiatrists became both social engineers and, for some of them, political activists. This section and the next reflect on the significance of these observations.

The most compelling change brought about in debates on psychiatric reform in mid-twentieth century France concerned the broad configuration of actors who participated in them: the actors who took the lead in these debates, the networks in which ideas circulated and the arenas where negotiations took place. A single example conveys the thrust of this change: whereas reform of the psychiatric system had been discussed continuously in the French Parliament until 1939, it received no new project after the war and until the 1980s. While congressmen had led the way in the denunciation of asylums and the suggestion of alternatives before the war, they practically deserted the field after 1945. In a way, this shift had been anticipated by the French minister of health himself at the end of the 1930s. Reacting to another defeat at obtaining approval of a new mental health law in the Senate, he asserted that it was time to "change method" in psychiatric reform (Conseil supérieur de l'assistance publique, 1937). Instead of devising new laws for regulating the system, the ministry should act directly on the mental health system through administrative rulings and the setting up of standards. Instead of relying on an elected body of congressmen, technicians and professionals would become the intermediaries of reform.

This shift was neither simply a matter of the legal means of political action, nor the consequence of the establishment of a new political regime with the advent of the Fourth Republic in 1946. What was at stake was a conception of the expertise needed for such a

\footnotetext{
${ }^{5}$ See for example the autobiographical reflections of the sociologist and mental health activist Robert Castel in the late 1980s (Castel, 1989).
} 
reform and of the overall framework in which reform should be developed. Consider the two commissions which led consultations on psychiatric reform before and after the war: the Conseil supérieur de l'assistance publique, which oversaw all major projects during the first half of the century, and the Commission des maladies mentales, which devised the "secteur" policy during the 1950s. The Conseil supérieur de l'assistance publique had been created with the mandate to carry out the political project of the French Revolution in the field of social welfare. In the report which would lead to its creation in 1888 , the prime minister wrote: "The French revolution laid down the principle of public assistance in precise and resolute terms, making it a pressing social duty, a sacred debt. It is our democracy which must be responsible for this duty and enlarge upon it both through broad private initiative and through generous administrative support.” (Conseil supérieur de l'assistance publique, 1888) As a consequence, the Conseil was conceived of as a body bringing together, as equals, elected representatives and members of civil society on the one hand and technicians, that is administrators and professionals, on the other.

This openly political project behind the origin of the Conseil contrasted sharply with the discussions and context behind that of the Commission des Maladies Mentales after the war. The Commission was created in 1947 after a petition by the secretary of the Union of psychiatric hospital physicians, George Daumézon. In his addresses to colleagues in the journal of the Union, Daumézon explicitly stated that the Commission would serve to keep the Ministry of Health informed of the changing conditions of psychiatric work and thus influence its policies in the mental health field (e.g.Daumézon, 1946). As a result, the Commission was set up as an independent committee, only later to be integrated into a larger Conseil permanent d'hygiène sociale. Its participants were essentially professionals deemed representatives of the diverse segments of the mental health world: of psychiatry itself as well 
as of the other mental health professions such as nurses and directors, and members of the health administration. No elected representative or member of any association was part of the discussions. As we shall shortly see, this also meant that reform projects would take on a far different perspective than before the war.

In many ways, these post-war developments can be analyzed as an outcome of the way the idea of reform itself, its actors and the arenas where it was articulated, had evolved up to that time. Two broad phenomena can account for these changes. The first was the development of medical specialization. As has been recently demonstrated by George Weisz (2006), specialization should not only be seen as the growth of specialized practice, but more fundamentally as a series of transformations in the regulation of the medical profession in the face of its growing fragmentation, whether inside medical institutions, hospitals and universities, through organizations financing health, or through the actions of medical associations. The process thus led to the emergence of new modes of accreditation and representation of the medical profession at the State level.

Several aspects of these processes played a role in the French debates about psychiatric institutions. The first was the development of specialized practice in large cities beginning in the last decades of the nineteenth century, with the emergence of a new population of officebased specialists in mental disorders, which was evidence of the strengthening of a collective identity (Weisz, 1994). The second aspect, beginning in the 1890s, was the reorganization of the group of asylum physicians by the ministry. Attempts at raising their social status included the creation of a national competitive examination in 1888. Meanwhile, alienists created an annual conference in 1890 and then, in 1905, a corporate structure, the Amicale des Aliénistes, to discuss their professional problems. During the 1920s, the emergence of mental Hygiene 
movements constituted the third aspect (Ohayon, 1999; Thomson, 1995; Wojciechowski, 1997). Modeled after French associations against cancer and tuberculosis and the American National Committee for Mental Hygiene, the French Ligue d'hygiène mentale set as its goal the publicizing of work by specialists and contributed to a new form of professional lobbying. Finally, following the Second World War, the creation of overarching regulations for specialties by the State in the context of the establishment of a national health insurance system, resulted in new representation of professional organizations within the State apparatus and the strengthening of the alignment of psychiatrists behind their unions (Weisz, 2006). These different elements resulted in increasing the collective expertise of the specialty. Whereas, up until the interwar period, discussions on the reform of the asylum were led within the medical profession by more or less isolated individuals, henceforth, propositions were made in the name of professional organizations. The best illustration of this trend is the fact that the union of psychiatric hospital physicians made institutional reform their main priority in the years 1940 to 1970 , above and beyond the defense of the interests of the group ${ }^{6}$.

The development of health bureaucracies was the second series of transformations and occurred within the State apparatus itself. The emergence of public health, the management of public assistance facilities, the creation of systems of social insurance and the development of hospital policies led to the setting up of offices, to the creation of positions for functionaries and the development of new methods of medical and administrative intervention. In France, an important step was the creation of the Ministry of Health in the early 1920s, although its resources and personnel where not really strengthened until the 1940s (Murard and Zylberman, 1996). In 1945, a public health inspectors’ corps composed of State-employed physicians was created, while a system of localized health ministry offices was set up. Mainly

\footnotetext{
${ }^{6}$ See the collection of the bulletin of the union, L'information psychiatrique.
} 
responsible initially for health surveillance and the regulation of public assistance, the health ministry saw its role evolve to encompass health promotion activities. The setting up of social insurance beginning in the 1920s also gave rise to the creation of a bureaucracy to manage the considerable new funds that were brought into the health system and to control their use. During the 1950s, as more funds were allocated to the construction and renovation of hospitals, a new administration was set up to supervise the process in an effort to rationalize the French health system. Its competence encompassed both the development and the enforcement of construction norms and, increasingly, the control of hospital budgets (Maillard, 1986). In addition, the development of these different administrative structures resulted in the multiplication of commissions and committees - among which was the Commission des maladies mentales - where professionals were called upon to give their opinions and that henceforth became new places where health problems were defined. While the administration of health institutions had been largely decentralized and organized by voluntary actors before the war, it now emerged as a new field of expertise subject to centralization and rationalization.

In many ways, both processes were a consequence of the way health care reform had been envisioned and implemented at the turn of the century. Health bureaucracies grew as a result of the need to administer the new flow of money that followed the creation of new rights to social and health services. The reorganization of the health professions was also a consequence of the need for personnel to run these services. A significant aspect of these processes was also the rise of international health organizations during the twentieth century, such as the international congresses of medicine, the international congresses of mental hygiene, or, in the post war period, the World Health Organization or the World Congress of Psychiatry (Henckes, 2009; Weindling, 1995). Because these organizations couldn’t intrude 
into the affairs of States and challenge their sovereignty, their involvement had to take the form of technical advice developed by medical experts.

The emergence of the postwar medical expert was the consequence of these various processes: he was a clinician imbued with new social authority but who in return was accountable to the State for the way he treated his patients. As was demonstrated by Weisz and colleagues (2007) in the case of the USA, State authorities were also in a position to impose a new set of norms on his work, in the form of guidelines or standards. These norms would now be the new way of regulating institutions.

\section{Framing alternatives to the asylum}

There should be no doubt that these changes in professional and administrative networks laid the groundwork for new ways of envisioning change in the field of psychiatry after World War II. Not only did new actors raise new questions, but they also developed specific ways of asking those questions. Analyses of psychiatric reform movements during the twentieth century have not often highlighted this specificity. Yet, in the French case, in comparison to discussions over the mental health system during the first half of century, a number of core issues disappeared from debate after the war. While committal procedure had been a central issue for basically all reform projects before the war, no serious discussion was organized around this issue until 1990, with the exception of one failed attempt in the 1960s. In the same vein, guardianship was reformed in 1968 but no debate had been organized on this topic since the 1940s, whereas it had been one of the major issues before the war. Preoccupation with the status of mental patients, which had been so strong before the war, seemed to no longer be important after the war. 
Instead, post-war discussions about psychiatric institutions were characterized by a focus on their concrete organization. Psychiatrists insisted on the need to have the means to adapt psychiatric institutions to their concept of psychiatric work. Health administrations developed a preoccupation with improving medical standards of psychiatric care. As a consequence, reforming hospitals became a matter of technical discussions led by technicians alone. Reform was to take the form of norms and standards, not abstract principles. The size of psychiatric hospitals, their architectural form, their location, their coordination within the rest of the health system, and the training of their personnel all became the focus of new and divisive controversies.

To a large extent, the rationale for this vision of reform had been developed outside the psychiatric world by the planning movement (Crozier, 1965; Rousso, 1986). In post-war France, planning emerged both as an ideology of state intervention developed by a small number of avant-garde political, administrative and professional elites, and as a series of administrative practices. Among the latter was the national Plan, launched in 1947, which was supposed to organize the reconstruction and economic growth of France after its collapse during the war and which integrated health in 1953. Above all, the Plan was conceived of as an arena for discussion among French economic actors. As was analyzed by sociologists in the 1960s, planning conveyed a new culture of public action, which entailed strategic thinking instead of the establishment of guiding principles, negotiation instead of control by State authorities, and the integration of influence into the power structure (Crozier, 1965).

In the mental health field, a first step in this direction was the discussion, stimulated by mental hygiene advocates, about “open services” during the interwar period (Huteau, 2002; Thomas, 2004; Toulouse et al., 1922). Modeled after an in vivo experiment led in Paris by 
Edouard Toulouse, open services were facilities where patients could be treated without any sort of administrative procedure. Although they were in a way just an expansion of innovations discussed and experimented with since the end of the nineteenth century, open services thus introduced a radical novelty: the possibility that reform in the mental health system could be achieved by creating new institutions, without changing rules governing existing ones. This was made clear when the Ministry of Health proposed a law to organize these new services and psychiatrists replied that such a law would damage the initiative (1924). Instead, one should encourage local actors to experiment in creating open services.

In many ways, post-war discussions accentuated this change of direction. The series of discussion organized at the Commission des maladies mentales which led to the "secteur" during the 1950s illustrates this, but other examples could be given (Henckes, 2007). The development of the secteur originated in 1953 during discussions on preparing the health section of the national plan ${ }^{7}$. The ministry had presented a series of propositions, based on a series of indicators limited to the number of beds per inhabitants. The leaders of psychiatric hospital physicians argued that the ministry should not give norms just for hospitals, but that it needed to develop a new framework to plan the entire psychiatric system. In the following years discussion intensified on the way this framework should be envisioned. At a meeting organized in November 1955, a group of psychiatric hospital physicians suggested that psychiatric norms should be defined locally by practitioners actually in charge of running the system, who would thus be given a new planning role. In response, a group of university teachers advocated that planning the psychiatric system should rely on general norms elaborated by a small group of specialists at the national level. Some aspects of the discussions also concerned the extension of the psychiatric system, the role of outpatient

\footnotetext{
${ }^{7}$ Archives of the Commission des maladies mentales, Archives Nationales, file number: 19950173.
} 
facilities in the system and whether to give priority to rehabilitation or to medical care. Eventually, the Ministry of Health proposed a compromise between those two visions in a circular published in March 1960, which proposed that local health authorities develop plans based on proposals made by psychiatrists. The secteur thus emerged primarily as a planning device, even though psychiatrists considered that it brought about new ways of thinking about their work. In the following years, the secteur would be considered as the French way of deinstitutionalizing psychiatry. This had certainly not been its initial objective.

This manner of addressing reform had a series of consequences. As mentioned earlier, one of them was to make impossible a discussion on a series of core issues for the psychiatric system, such as procedures for committal or guardianship. Another consequence was to recast the debate on the specificity of the psychiatric system in relation to the rest of the medical world. In the wake of discussions on open services, a radical position, supported in particular by the mental hygiene movement, had been the suggestion to end the special status of psychiatry by integrating its services and its professionals within the general hospital system. By contrast, in the years following the war, the leaders of psychiatric hospital physicians hoped that by allocating supplementary medical resources to their institutions, these would more closely resemble general hospitals (Lauzier et al., 1946). Again, norms and standards were thought to be the best way to realize convergence with colleagues. Beginning in the 1960s, a change in the status of general hospitals, turning their medical personnel into state employees, eventually made this convergence possible.

In many respects, then, the history of the idea of reform within the field of psychiatry reflected the transformation of health into an object for public intervention. In Post-War France, reforming psychiatric institutions was no longer equated with an issue of justice or 
human rights. Instead, it became a question of creating a new context for psychiatric care. A major aspect of this change was the new attitude many professionals took toward their institutions and working within them.

\section{Psychiatric reform and psychiatric work after 1945}

There was a concrete sense in which one could say that reforming psychiatry became a way of doing psychiatry in the post-war period. In a way, it was encapsulated in the focus on social psychiatry and the ideas it embodied, namely that social life was an important factor in the onset of mental disorders and that institutions could be turned into instruments for treating patients by developing social activities and by rethinking their organization. Sociologists or historians who have analyzed such movements as psychotherapeutic communities or, in France, institutional psychotherapy (psychothérapie institutionnelle) have oscillated between two stances: the first is to denounce these movements as mere ideologies (Castel, 1973); the other is to analyze the ideas and concrete practices as if they had meaning only at the level of therapy (for such an analysis in the British context: Bloor et al., 1988; Thalassis, 2007; for such an analysis in the British context: von Bueltzingsloewen, 2007). They have only rarely insisted on the fact that these practices themselves developed into a political project. In this light, research should consider these practices not only as mere practical innovations. It should also address the conditions in which a variety of practices considered as revolutionary by actors have emerged simultaneously in a diversity of sites, under the impetus of a variety of professionals.

In the French case, much has been written about the experiments in institutional psychiatry led by the group of young psychiatrists who took the lead in the profession after the war. One site for these experiments was the psychiatric hospital at Saint Alban in southern France, 
where a series of practices were developed in the 1940s in occupied France and became a symbol of French psychiatry's renaissance after the war (Fourquet and Murard, 1975; von Bueltzingsloewen, 2007). Other experiments were carried out in the Paris region by psychiatrists such as Paul Sivadon and Louis Le Guillant, who, with the help of the Social security, reorganized their wards around patient rehabilitation (Fourquet and Murard, 1975). Later on, other experiments would serve to develop the secteur psychiatry, most notably in the thirteenth arrondissement of Paris (Henckes, 2005). But there has not been as much writing about other significant experiments that found less support in the profession or among the general public.

Consider for example the case of Agnès Masson, a psychiatrist working in Châlons sur Saône in eastern France. In 1944, as the first woman to hold the position of director in a psychiatric hospital, she began to develop social activities and to create a new atmosphere for patients and professionals within her hospital, a project soon known as the "expérience de Châlonssur-Saône”. In 1948 she published a book summarizing her ideas about psychiatric reform and for a few months in 1952 she edited a journal, l'Assistance psychiatrique, devoted to the problems of psychiatric hospitals, with articles by herself and other psychiatrists she felt shared her ideas. While she obtained some success in the local political milieu, her writing soon attracted criticism from leading psychiatrists, who treated her work as a "caricature" of social psychiatry, and her activity also got her into trouble with her superiors: in 1947 she was suspended by the Ministry of Health from her position as hospital director and sent to another hospital in northern France. In the following years, she had to move several times from place to place, and in 1955 she abandoned the career of psychiatric hospital physician.

Or consider the case of Jean Ueberschlag, senior psychiatrist at the psychiatric hospital of 
Lannemezan in southern France, who also developed an experiment in social psychiatry beginning in 1948. In the late 1940s his ward became an often mentioned model, and he himself obtained recognition for his work from the Minister of Health, who named him to the Commission des maladies mentales in 1955. But in the mid 1950s, he was the center of controversy when a "police room" was discovered in his ward, where ceremonial punishment was organized for difficult patients who disrupted the institutional order. Masson as Ueberschlag were both entrepreneurs who, like other figures in the profession, felt they had the mission and the power to change psychiatric institutions from within. Both of them probably thought the opposition they faced was simply resistance to the changes brought about by their endeavors. Their stories are thus suggestive of the way in which reforming psychiatric institutions became a project which many psychiatrists felt they must pursue in their daily work. They also testify to the fact that the field of reform was a competitive one.

Two factors can be considered in order to understand the dissemination of this spirit of reform among professionals. The first was of course the new discourse about institutions developed by social psychologists and sociologists. The techniques of group psychotherapy and the theory of group dynamics developed after the 1930s enabled the emergence of a new kind of intervention in social systems in general and in psychiatric institutions in particular. In France, these practices were first disseminated immediately after the war under the impetus of psychologists and psychiatrists who created psychotherapeutic groups in a number of medical or medico-social facilities (see for example Lebovici et al., 1952). The implementation of these ideas at the level of institutions themselves using institutional psychotherapy was simply going one step further. For psychiatrists involved in this movement, the contribution of group dynamics lay less in a given program than in the incentive it gave to cast a critical eye on existing practices. Turning an institution into one which was therapeutic depended on an 
analysis and awareness of how it functioned, including its least important aspects (see Daumézon, 1948). This attention to the mundane aspects of daily institutional life led those psychiatrists to develop an extreme form of reflexivity. Experiments in institutional psychotherapy were valuable as much, if not more so, for their atmosphere of authenticity and the participation they inspired among the actors, as for the means they employed. This concerned all aspects of psychiatric work. A widespread opinion after the war was that the efficacy of shock therapies could be explained mainly by the newfound involvement they gave rise to among nurses ${ }^{8}$.

But this reflexivity was not only a discursive technique. Most articles about institutional psychotherapy, its theory and method, developed a form of retrospective theorizing in order to understand under what conditions these experiments might be reproduced. In many ways, they could be read as a reflection on the question of what it meant to be a reformer. For example, a 1955 article on "How to create a useful community life for patients in psychiatric institutions”, summing up the author's accumulated experience over the preceding decade, took the form of a vivid portrait of a psychiatric hospital physician taking over a post in a remote hospital and progressively imposing a new vision of psychiatry on his coworkers, one that broke with the routine they were used to (Daumézon, 1955). To attain this goal, the psychiatrist needed to shape his image among nurses in order to persuade them to develop a more spontaneous involvement in therapeutic activities. In the end, this analysis amounted to theorizing about the charismatic powers of psychiatric hospital physicians and their ability to encourage those around him to adopt an attitude of change. There was no better illustration of the intricacy of issues of therapy and reform in the minds of those psychiatrists.

\footnotetext{
${ }^{8}$ This analysis was first developed by psychiatrists from Saint Alban during the war (Balvet et al., 1942).
} 
But another element was also important for those experiments. It related to the new career possibilities offered to psychiatrists in a period of expansion in their discipline that also saw State agencies, local authorities and the media support numerous projects. The renewal of social and political elites brought about by the Second World War and the profound transformations that the warfare state, then the setting up of the welfare state, initiated in the administrative and political structures of the Western States, strongly affected the medical professions as well. In France, the emergence of the young reformist psychiatrists who would influence the postwar period until the 1960s was directly related to the reorganization of the State following Liberation. Supported by established figures in French psychiatry such as Henri Ey, these young psychiatrists benefited from their participation in the medical Resistance movement and its associated networks in order to obtain entry into the new health administration (Fourquet and Murard, 1975). The quasi revolutionary climate in the months following Liberation, which allowed governments to initiate numerous reforms, particularly in the health and social fields, offered them a window of opportunity for beginning to think about reform in psychiatry. This series of circumstances would later on constitute the founding event on which these psychiatrists would build their commitment to reform over the following years.

This situation was also found at the local level. Growth in the health budget created an interest among authorities for innovation. The increase in the size of mental health services also made it necessary to rethink their organization in many locations. Some psychiatrists were thus able to obtain the permission and means from local authorities to develop innovative experiments and practices, as in the Paris region with institutional psychotherapy and secteur psychiatry. The numerous therapeutic innovations that appeared during the three decades following the war, from shock therapies to psychotropic drugs, as well as different forms of psychotherapy, 
were all factors that shaped the undertakings while providing their justification.

The development of an attitude of reform among a large number of professionals was also related to evolution in the recruitment of health care personnel for psychiatric facilities. The creation of numerous job positions in health and social institutions during the 1950s and ' 60 s led to a flood of new people with the will to transform conventional practice. In France, the number of positions within State psychiatric hospitals tripled from 180 to 550 between 1950 and 1965, before being multiplied by four until the 1980s. The creation or spread of new professions such as those of psychoanalyst, psychologist, work therapist, or social worker depended on the ability of actors to invent new roles which in turn brought about change in institutional routines. These different categories were also the avant-garde of a new and rising middle class which played a key role during the 1960s in disseminating a broad interest for the human sciences and for cultural progressivism throughout society (Muel-Dreyfus, 1983).

In many places, the simple replacement of a hospital physician in his post for several years by a younger colleague could lead to an impression of profound renewal. In France, the evolution of psychiatric careers played a key role in these dynamics (Henckes, 2007). After the war, changes in the recruitment examination for asylum physicians had created a standard career profile. Each year, posts vacated by retirement were offered to the entire professional body according to seniority. New arrivals inherited those posts their seniors left to them. Thus, young physicians were usually posted to the most remote establishments, which they left as soon as possible when a better post became vacant but where, in the meantime, they could have the feeling of bringing a whiff of change, inspired by the latest advances from Paris. In addition, their relationships with patients as well as with nurses were characterized by a social and cultural distance that reinforced the image they had of themselves as missionaries. 


\section{The evolution of reform movements}

The multiplication of calls for reform in psychiatry after the war could thus be linked both to the conditions in which psychiatry was practiced during the period and the way a segment of the discipline envisioned its work in institutions. A history of these reformist vocations must also consider what became of the numerous projects they created, beyond the initial period of enthusiasm surrounding them. As with every entrepreneur, psychiatric reformers were eventually overcome by disenchantment. This could be explained by the process of institutionalization and routinization of innovations, by their exhaustion when they were overtaken by disappointment in respect to their own accomplishments, by the emergence of new actors taking up the flame of reform and who considered earlier reforms to be out of fashion, or by changes in the general context into which they were integrated. In the end, the rapid renewal of the generations of reformers and the continual shifting of the centers of innovation between the end of the 1940s and the 1970s was a consequence of the impossibility of attaining the goal of a psychiatric institution cleansed of its faults, but also of the difficulty of maintaining the long-term commitment of the actors.

During the 1950s, criticism of initial post-war institutional experiments rapidly led outpatient facilities to become the focus of the reform movement. In the Anglo-Saxon world, this movement was illustrated by the critical shift taken in the social scientific analysis of psychiatric institutions, illustrated by Goffman’s Asylum (1961) and, at the same time, by the development of community mental health centers. In France, the group of reforming psychiatrists that had emerged immediately after Liberation was able to stay in the avantgarde of the movement by renewing its approach. The 1950s saw a number of them coming to the conclusion that their experiments in institutional psychotherapy had led to a dead end, giving rise to tensions in their group concerning the meaning of institutional practices (Ey et 
al., 1952). In the following years, as they were trying to develop a new project to overcome these difficulties, discussions at the Commission des maladies mentales encouraged them to engage in broader reflections on the role of the psychiatric hospital within the mental health system, which led in 1960 to the secteur, thus enabling the group's reform initiative to be restarted.

In a way, the situation was repeated at the end of the 1960s and during the 1970s in a different context, marked by both the diversification of actors and the first incentives towards deinstitutionalization. The increasing role of certain categories of professionals within psychiatric institutions, psychologists and social workers in particular, in conjunction with the creation of new social services outside medical institutions, such as half-way houses or nursing homes, and the professionalization of paramedical personnel in general, enabled the emergence of new voices demanding a new approach by institutions. The social movements at the end of the 1960s also provided new models for challenging psychiatric practices, founded on such diverse ideologies as Lacanian psychoanalysis or on political radicalism. For example, among the former was the experimental school headed by Maud Mannoni or the La Borde clinique in western France, while the latter included attempts at creating movements uniting users and professionals, such as the Groupe Information Asile, modeled on the Group Information Prison created by Michel Foucault (see Castel, 1982; Turkle, 1978). Taken together, these different movements demonstrated a new openness by psychiatry toward society. In the social sciences, increasing condemnation of institutions and mounting discussion of social control were a reflection of a radicalization of criticism, which in turn influenced professional rhetoric. At the end of the 1970s, the adoption of anti-institutional rhetoric by the Ministry of Health in the conservative government of President Giscard d'Estaing in order to justify a reduction in social expenditures was but one aspect of this 
success, a move similar to developments in Anglo-Saxon countries condemned by such thinkers as Peter Sedgwick (1982).

These movements did not prevent the practices themselves from continuing in care facilities. Techniques developed immediately after the war, including group therapy, ergotherapy, the practice of staff meetings or the new style of interaction between psychiatrists and their coworkers defined a form of practice which still prevails today in many places. As shown by Catherine Füssinger, it is difficult to say that practices developed by antipsychiatrists during the 1960s and'70s were more liberal or liberating than those of the first therapeutic communities (Fussinger, in this volume). Another aspect concerns technical norms that may survive even though the ideas on which they were based have become outmoded. This was the case for a number of guidelines that were created for regulating psychiatric services. In France, up until the 1970s, the construction of facilities followed the norms developed immediately after the war, which envisaged large institutions established on vast properties even though the secteur policy has insisted since the 1960s on the necessity of building small facilities that were incompatible with these norms.

\section{The changing regulation of the psychiatric institution}

As many historians and sociologists have noted, we should probably stop thinking that deinstitutionalization was in any strong sense related to the innumerable reform movements which emerged in psychiatry during its long history (Jones, 1993; Scull, 1977). But this doesn't mean these movements are uninteresting or that we shouldn't try to understand them, the motivation of their actors and the way in which they developed their action. In fact , one lesson of the long story of reform in the field of psychiatry can probably be found, not at the level of social change, but at the level of changing concepts of social change and, more 
specifically, of the relationship between professionals and the State as actors in these concepts. Indeed, the history of psychiatric hospitals is to a large extent a history of the functions and organization of Western States, of their justifications, and of their relationships with society.

The middle of the twentieth century obviously marked a key stage in a movement in which the States took a growing role in the definition, management and operation of mental health systems. While France may be a particularly extreme example of this process, it affected other Western countries as well. The federal program of Community Mental Health Centers in the United States and the mental health policy led by the NHS in Great Britain are significant examples of this. However, beyond this general conclusion, one issue in the analysis of reform movements in psychiatry in the mid twentieth century is how to bring clarity to the specific modalities of State intervention in psychiatric affairs. It is necessary to pay attention to who in fact is the State, on the way its relationships with local authorities and professionals are actually organized, on the exact role of all these actors in defining and managing activities in mental health. It is also necessary to pay heed to State ideologies, the way these ideologies were developed at the national but also the international level and the way they actually framed the actors' behavior.

Approaches in terms of social control in the 1970s and '80s strove mightily to depict the development of mental health policies as an extension of control by the State over populations and individuals, with psychiatrists simply playing the role of agents of this control. While indeed, during a large part of the nineteenth century, the intervention of the State in the organization of the psychiatric system could be seen to derive from its role as the guarantor of social order, beginning with the twentieth century, with the rise of welfare states, State 
interventions began to change to encompass regulation of medical work itself. As seen above, this took a variety of forms: one was the assimilation by the State of medical expertise; another was the involvement of the State in the definition of a certain number of technical standards for medical work.

In France, this movement also resulted in a new dynamic of State involvement in the field. Whereas experiments before the war were based primarily on local initiatives which then sought national recognition, conversely, in the 1950s and '60s the opposite dynamic was put in place, with initiative from the top down. Institutional experiments depended on resources distributed by the State and were marked by strong involvement of State representatives in releasing funds, providing their symbolic support and sometimes participating directly in the definition of the methods employed. The leading experiment in secteur psychiatry during the 1960s and '70s, the Association de santé mentale et de lutte contre l'alcoolisme in the $13^{\text {th }}$ arrondissement of Paris, is the best example of this pattern (Henckes, 2005). Initiated by a psychiatrist from the Parisian health administration, it was strongly supported by the office of psychiatry in the Ministry of Health and by administrators from the National Social Security Fund. The representatives of these two bodies participated closely in the preparation of the experiment and its adaptation throughout its first decade of existence, even making suggestions for the construction of facilities, on how to obtain financing, but also on how to use the resources. In contrast, local public figures were notably absent from the board of supervisors of the Association and not involved in the day to day life of its services.

This dynamic obviously played a key role in the way psychiatrists became involved in reform after the war, and the limitations they encountered starting in the 1970s. I mentioned above the recruitment procedures for physicians in psychiatric hospitals in France. During the 1950s, 
numerous publications testify to the fact that psychiatrists felt themselves to be invested with a quasi civilizing mission. With a clear mandate from higher health administration authorities, motivated by a strong feeling of scientific legitimacy, they saw themselves as the sole persons responsible for and the master builders of the psychiatric system, in spite of any resistance they might meet. They felt they could speak in the name of all actors of psychiatry, and above all for the patients, for whom they considered themselves to be the sole legitimate representatives. Both players and referees in the psychiatric game, they considered themselves alone in being able to define the limits of their function. It is in relation to this psychiatric dominance that the antipsychiatry protest movements of the 1970s take on their meaning. By emphasizing what this authority owed to the social structure of Western countries after the war, these criticisms revealed in a way its fragility and limits. Their impact brought about the end of the reforming ideal in psychiatry.

\section{Acknowledgment}

I thank the editors of this issue as well as two anonymous reviewers for their helpful comments. I also thank Jon Cook for his help with the English version of this article.

\section{References}

(1924) Les services ouverts. Annales Médico-psychologiques I: 370-374

Armstrong D (1995) The rise of surveillance medicine. Sociology of Health and Illness 17: 393-404

Bachrach LL (1976) Deinstitutionalization: An analytical review and sociological perspective Rockville, Maryland: National Institute of Mental Health

Balvet P, Chaurand A, Tosquellès F (1942) Considérations techniques et statistiques sur 60 malades traités par électrochoc. In: Congrès des médecins aliénistes et neurologistes de France et des pays de langue française. XLIIIe session. Montpellier, 28, 29, 30 octobre 1942. Comptes rendus, Combemale P, Hugues P, eds. Paris: Masson

Barham P (1992) Closing the asylum: the mental patient in modern society Harmondsworth: Penguin

Berrios GE ed. (1996), The history of mental symptoms. Descriptive psychopathology since the nineteenth century. Cambridge: Cambridge University Press

Bloor M, McKegney N, Fonkeyrt D (1988) One foot in Eden. A sociological study of the 
range of therapeutic community practice Londres-New York: Routledge

Blumer H (1969) Symbolic interactionism. Perspective and method Englewood Cliffs, NJ: Prentice Hall

Boltanski L, Thévenot L (2006) On justification: economies of worth Princeton: Princeton University Press

Braslow J (1997) Mental ills and bodily cure: Psychiatric Treatment in the First Half of the Twentieth Century Berkeley (CA): University of California Press

Brown P (1985) The transfer of care: Psychiatric Deinstitutionalization and its Aftermath London, Boston: Routledge and Kegan Paul

Burnham JC (2000) Jack Pressman and the future of the history of psychiatry. Bulletin of the History of Medicine 74: 778-785

Castel R (1973) Le psychanalysme Paris: François Maspéro

Castel R (1982) La gestion des risques. De l'anti-psychiatrie à l'après psychanalyse, Bourdieu P ed. Paris: Ed. de Minuit

Castel R (1988) The regulation of madness: the origins of incarceration in France. U.S. edition Berkeley: University of California Press

Castel R (1989) De l'intégration sociale à l'éclatement du social: l'émergence, l'apogée et le départ à la retraite du contrôle social. In: L'éclatement du social. Crise de l'objet, crise des savoirs? Le Gall D, Martin C, Soulet M-H, eds. Caen: Université de Caen. Centre de recherche sur le travail social, pp 173-185

Castel R (1991) From dangerousness to risk. In: The Foucault Effect: Studies in Governmentality, Burchell G, Gordon C, eds. Chicago: The University of Chicago Press, pp 281-297

Clarke A (2005) Situational analysis: Grounded theory after the postmodern turn Thousand Oaks, Calif.: Sage Publications

Conseil supérieur de l'assistance publique (1888) Fascicule $n^{\circ} 1$. Constitution du Conseil Melun: Imprimerie administrative

Conseil supérieur de l'assistance publique (1937) Fascicule $n^{\circ}$ 145. Session ordinaire de 1937 Melun: Imprimerie administrative

Cooter R (2007) After Death/After-'Life': The Social History of Medicine in PostPostmodernity. Social History of Medicine 20: 441-464

Crozier M (1965) Pour une analyse sociologique de la planification française. Revue Française de Sociologie VI

Daumézon G (1946) Rapport moral. Information Psychiatrique 22: 152

Daumézon G (1948) Les fondements d'une psychothérapie collective. Evolution Psychiatrique: $57-85$

Daumézon G (1955) La vie collective du malade mental. In: Encyclopédie française. XIV. La civilisation quotidienne Paris, pp 7-13

Dowbiggin IR (1991) Inheriting madness: professionalization and psychiatric knowledge in nineteenth-century France Berkeley: University of California Press

Estroff SE (1981) Making it crazy: an ethnography of psychiatric clients in an American community Berkeley: University of California Press

Ey H, Sivadon P, Tosquellès F, Le guillant L, Daumézon G (1952) Symposium sur la psychothérapie collective. Evolution Psychiatrique: 531-592

Fauvel A (2005) Témoins aliénés et "nouvelles Bastille". Une histoire politique, sociale et culturelle des asiles en France (1800-1914). Thesis. Type, Ecole des Hautes Etudes en Sciences Sociales, Paris

Foucault M (1975) Surveiller et punir. Naissance de la prison Paris: Gallimard

Fourquet F, Murard L (1975) Histoire de la psychiatrie de secteur ou le secteur impossible? Recherches 
Gijswijt-Hofstra M, Oosterhuis H, Vijselaar J, Freeman H eds. (2005), Psychiatric cultures compared: psychiatry and mental health care in the twentieth century: comparisons and approaches. Amsterdam: Amsterdam University Press,

Goffman E (1961) Asylums. Essays on the social situation of mental patients and other inmates. [1st edition Garden City, N.Y.: Anchor Books

Goldstein JE (1987) Console and classify: the French psychiatric profession in the nineteenth century Cambridge [Cambridgeshire]; New York: Cambridge University Press

Goodwin S (1997) Comparative mental health policy. From institutional to community care London: Sage

Grob GN (1991) From Asylum to Community. Mental Health Policy in Modern America. Princeton: Princeton University Press

Gusfield JR (1981) Drinking-driving and the symbolic order: the culture of public problems Chicago: The University of Chicago Press

Hacking I (1995) Rewriting the soul: multiple personality and the sciences of memory Princeton, N.J.: Princeton University Press

Healy D (1997) The antidepressant era Cambridge, Mass.: Harvard University Press

Henckes N (2005), Réformer la psychiatrie, organiser les pratiques de secteur. La construction de la psychiatrie de secteur dans "l'expérience du treizième arrondissement": Rapport pour le programme Sciences biomédicales, Santé, Société, MiRe/INSERM/CNRS

Henckes N (2007) Le nouveau monde de la psychiatrie française. Les psychiatres, l'Etat et la réforme des hôpitaux psychiatriques de l'après-guerre aux années 1970. Thesis. Type, Ecole des hautes études en sciences sociales, Paris

Henckes N (2009) Narratives of change and reform processes: Global and local transactions in French psychiatric hospital reform after the Second World War. Social Science \& Medicine 68: 511-518

Huteau M (2002) Psychologie, psychiatrie et société sous la troisième république. La biocratie d'Édouard Toulouse (1865-1947) Paris: L'Harmattan

Jones K (1993) Asylums and after. A revised history of the mental health services: from the early 18th century to the 1990s London: Athlone

Lauzier J, Balvet P, Le Guillant L, Daumézon G, Hemphill RE, Bonnafé L, Bernard P (1946) Au delà de l'asile d'aliéné et de l'hôpital psychiatrique. Documents de l'Information Psychiatrique, 2 Paris: Desclée de Brouwer

Lebovici S, Diatkine R, Kestemberg E (1952) Applications de la psychanalyse à la psychothérapie de groupe et à la psychothérapie dramatique en France. Evolution Psychiatrique: 397

Maillard C (1986) Histoire de l'hôpital de 1940 à nos jours Paris: Bordas

McCarthy JD, Zald M (1977) Resource mobilization and social movements: a partial theory. American Journal of Sociology 82: 1212-1241

Muel-Dreyfus F (1983) Le métier d'éducateur. Les instituteurs de 1900, les éducateurs spécialisés de 1968. Paris: Editions de Minuit

Murard L, Zylberman P (1996) L'administration sanitaire en France dans l'entre-deuxguerres. Le ministère de l'Hygiène: création et action, suivi de: Deux essais sur l'histoire de la coopération sanitaire internationale Paris: CERMES, Convention MiRe-INSERM

Ohayon A (1999) L'impossible rencontre. Psychologie et psychanalyse en France 1919-1969 Paris: La Découverte

Pressman JD (1998) Last resort. Psychosurgery and the limits of medicine Cambridge: Cambridge University Press

Prestwich PE (1994) Family strategies and medical power: "voluntary" committal in a 
parisian asylum, 1876-1914. Journal of Social History: 799-818

Prior L (1993) The social organization of mental illness London: Sage

Rose NS (2007) The politics of life itself: biomedicine, power, and subjectivity in the twentyfirst century Princeton, NJ: Princeton University Press

Rothman DJ (1980) Conscience and Convenience. The Asylum and Its Alternatives in Progressive America Boston: Little, Brown

Rousso H ed. (1986), De Monnet à Massé. Enjeux politiques et objectifs économiques dans le cadre des quatre premiers Plans (1946-1965). Actes de la table ronde tenue à l'IHTP les 24 et 25 juin 1983. Paris: Editions du CNRS

Scull A (1977) Decarceration: Community Treatment and the Deviant - A Radical View Englewood Cliffs, NJ: Prentice-Hall

Sedgwick P (1982) Psycho Politics. Laing, Foucault, Goffman, Szasz and the future of mass psychiatry Cambridge: Harper and Row

Swazey JP (1974) Chlorpromazine in psychiatry: a study of therapeutic innovation Cambridge, Mass.; London: MIT press

Thalassis N (2007) Soldiers in Psychiatric Therapy: The Case of Northfield Military Hospital 1942 1946. Soc Hist Med 20: 351-368

Thomas GM (2004) Open psychiatric services in interwar France. History of Psychiatry 15: $131-153$

Thomson M (1995) Mental hygiene as an international movement. In: International health organizations and movements, 1918-1939, Weindling P, ed. Cambridge: Cambridge University Press, pp 283-304

Tone A (2009) The age of anxiety: a history of America's turbulent affair with tranquilizers New York: Basic Books

Toulouse E, Genil-Perrin G, Targowla R (1922) L'organisation du service libre de prophylaxie mentale de l'Asile Sainte Anne. Annales Médico-psychologiques I: 338

Turkle S (1978) Psychoanalytic politics: Freud's French Revolution New York: Basic Books

von Bueltzingsloewen I (2007) L'hécatombe des fous. La famine dans les hôpitaux psychiatriques français sous l'Occupation Paris: Aubier

Weindling P (1995) International health organisations and movements, 1918-1939 Cambridge; New York, NY, USA: Cambridge University Press

Weisz G (1994) Mapping Medical Specialization in Paris in the Nineteenth and Twentieth Centuries. Social History of Medicine 7: 177-211

Weisz G (2006) Divide and conquer. A comparative history of medical specialization Oxford: Oxford University Press

Weisz G, Cambrosio A, Keating P, Knaapen L, Schlich T, Tournay V (2007) The emergence of clinical practice guidelines. The Milbank Quarterly 85: 691-727

Wojciechowski J-B (1997) Hygiène mentale et hygiène sociale: contribution à l'histoire de l'hygiénisme. Tome II. La ligue d'hygiène et de prophylaxie mentales et l'action du docteur Edouard Toulouse (1865-1947) au cours de l'entre-deux-guerres Paris: L'Harmattan 